\title{
Erratum on: Emotionality differences between a native and foreign language: theoretical implications
}

\author{
Frontiers Production Office* \\ Frontiers Production Office, Frontiers, Switzerland
}

OPEN ACCESS

Approved by:

Psychology Editorial Office,

Frontiers, Switzerland

*Correspondence:

Frontiers Production Office,

production.office@frontiersin.org

Specialty section:

This article was submitted to Language Sciences, a section of the journal Frontiers in Psychology

Received: 27 March 2015

Accepted: 27 March 2015

Published: 02 April 2015

Citation:

Frontiers Production Office (2015)

Erratum on: Emotionality differences

between a native and foreign language: theoretical implications.

Front. Psychol. 6:437.

doi: 10.3389/fpsyg.2015.00437

Keywords: bilingualism, emotion, context dependence, embodiment, language acquisition

\section{An erratum on}

Emotionality differences between a native and foreign language: theoretical implications by Caldwell-Harris, C. L. (2014). Front. Psychol. 5:1055. doi: 10.3389/fpsyg.2014.01055

Reason for Erratum: Recognition of an additional reviewer.

Due to an oversight, the following reviewer Lowri Mair Hadden (Bangor University, UK), who jointly reviewed the paper with her supervisor Debbie L. Mills (Bangor University, UK), was not acknowledged on the publication. This error does not change the scientific conclusions of the article in any way. The publisher apologizes for this mistake.

Conflict of Interest Statement: The author declares that the research was conducted in the absence of any commercial or financial relationships that could be construed as a potential conflict of interest.

Copyright $\odot 2015$ Frontiers Production Office. This is an open-access article distributed under the terms of the Creative Commons Attribution License (CC BY). The use, distribution or reproduction in other forums is permitted, provided the original author(s) or licensor are credited and that the original publication in this journal is cited, in accordance with accepted academic practice. No use, distribution or reproduction is permitted which does not comply with these terms. 